\title{
THE PROSPECTS OF THE RUSSIAN PERSONAL INCOME TAX REFORM IN RESEARCH PROCEEDINGS BY SCIENTISTS OF FOREIGN UNIVERSITIES
}

\author{
Nadezhda Ponomareva ${ }^{1}$, Ekaterina Golubtsova ${ }^{2 \star}$, Anna Pakshaeva ${ }^{3}$ \\ ${ }^{1} \mathrm{Ph}$. D., associate professor, associate professor of the Accounting and Taxation Department, \\ Plekhanov Russian University of Economics, Stremyannyj lane, 36, Moscow, 115054, Russia \\ email address: nvponomareva@mail.ru \\ ${ }^{2} \mathrm{Ph}$. D., associate professor, associate professor of the Accounting and Taxation Department, \\ Plekhanov Russian University of Economics, Stremyannyj lane, 36, Moscow, 115054, Russia \\ email address: katarina.golubtsova@gmail.com \\ ${ }^{3}$ Student of the faculty of the International business school, Plekhanov Russian University of \\ Economics, Stremyannyj lane, 36, Moscow, 115054, Russia email address: \\ annapakshaeva@mail.ru \\ ${ }^{*}$ Corresponding Author
}

\begin{abstract}
The experience of foreign universities in researching reforms of personal income taxation is especially interesting now for the Russian Federation as it plans to transfer from a proportional to a progressive personal income tax scale. Russia has the experience of using a progressive personal income tax, but it proved to be untenable because of minimal collection of taxes at the highest rate. The key objective of our research was finding the optimal tax rates and the number of personal income tax increments in the Russian Federation. The novelty of our research is in the use of indicators of several states to calculate the unknown quantity, while the custom here is adaptation of a foreign country's taxation system to local realities. The article presents comparative analysis of several foreign systems of progressive taxation of individuals, which take into account economic and social realities of each state. We compared indicators of the economies under research linked with the social features of taxation, national income distribution and the importance of the personal income tax for the budgets. Modern legislations establish different methods of calculating the taxation base for individuals, the rates. The research of foreign universities in the area of reforming personal income taxation, the extended experience of progressive personal income tax collection in these states and adaptation to Russia should help the Russian Federation introduce an effective progressive scale of the personal income tax. Basing on the data from 21 countries with a progressive personal income tax scale our research outlines several parameters of the personal income tax model, which could be used in the Russian economy taking into account the differences of local development indicators compared with their foreign analogues.
\end{abstract}

Keywords: income taxation, personal income tax, a progressive taxation scale, personal income tax rates.

\section{INTRODUCTION}

A lot of developed economies apply a progressive personal income tax scale. The Russian Federation also 
plans to resume the practice of taxing individuals with a progressive scale. At that, although taxes come in as "seizure," which is supposed to slow down development at the macroeconomic level, the bulk of economies under consideration is conspicuous for their high GDP growth rate. The use of their experience may have a positive effect on the efficiency of the local taxation system $[3,8]$. At the moment the issue seems to be debatable. Some experts state that a flat scale of a personal income tax improved legitimation of incomes and was beneficial for payments to the budget. Others say that it is not the new scale that the state should thank for a higher income of the consolidated budget. They attribute the positive trend to the growth of absolute incomes of the population and some other taxation novelties [13]. A lot of progressive scale models for individuals have been developed in Russia recently with various proposed rates. Some people suggest a return to the system Russia applied before the current flat scale $[15,17]$.

Using data from 21 countries, which apply a progressive personal income tax, our research has defined some parameters of a personal taxation model, which could be used in the Russian economy taking into account the difference between the Russian development indicators compared to foreign ones.

\section{LITERATURE REVIEW}

Scientists Matteo Morini, Simone Pellegrino (2018) [11] from the Institut Rhône-Alpin des Systèmes Complexes (IXXI) and University of Torino researched the algorithm of establishing the best structure of the personal income tax using Italy as an example and suggested the optimal rates to maximize the redistribution effect without increasing the tax burden of individuals. Blaine G. Robbins, Edgar Kiser (2020) [4] from the New York University Abu Dhabi, and University of Washington with the help of factorial analysis concluded that higher budget revenue from the personal income tax does not so much depend on the rates as on the society's values and state control over completeness and correctness of tax payments. Empiric research by Gabriele Ciminelli, Ekkehard Ernst, Rossana Merola, Massimo Giuliodori (2019) [7] revealed that tax-based consolidation reduces income inequality. This conclusion was done not only for personal taxation, but also for the consumption taxes. Riccardo Magnani, Luca Piccoli (2020) [14] assessed the results of a tax reform unrelated to the incomes, which introduces a universal scheme of basic income with a personal income tax. They used simulation model Micro-Macro for the French economy for the purpose. The results demonstrated that the reform reduces income inequality significantly. Carlos Bethencourt, Lars Kunze (2020) [5] studied relation between economic growth and tax evasions. The researchers note that the states with low incomes are characterized by a high level of income tax evasion. In this case a higher tax rate increases the share of evaders among the people and total tax evasion. Valerio Dotti (2020) [18] from the Washington University in St. Louis says that a higher income inequality implies a more progressive taxation system.

\section{MATERIALS AND METHODS}

Correlation and regression analyses were used in our calculations. Clustering analysis revealed the economies with a social structure similar to the Russian structure.

We artificially selected several elements, objective characteristics to help us create the scale we need to compile the model.

The tax rate models' elements:

- The number of brackets of the tax scale that determines the details of social stratification from the taxation point of view

- $\quad$ The maximum tax rate that sets the maximum allowable share of income required from the taxpayer

The average step between the brackets of the scale demonstrating sensitivity of the tax to the changes in revenue. Difficulties in calculations were conditioned by the presence in some countries of zero rates for some incomes similar to a tax-exempt minimum instead of a natural number of the initial rate [10]. This is why a model can be created by measuring an average step from the highest indicator, not from a zero value of the scale to avoid errors $[12,16]$

\section{RESULTS}

Our research analyzed several indicators of the countries under consideration and established their corresponding indicators for the Russian economy. (Chart 1) 


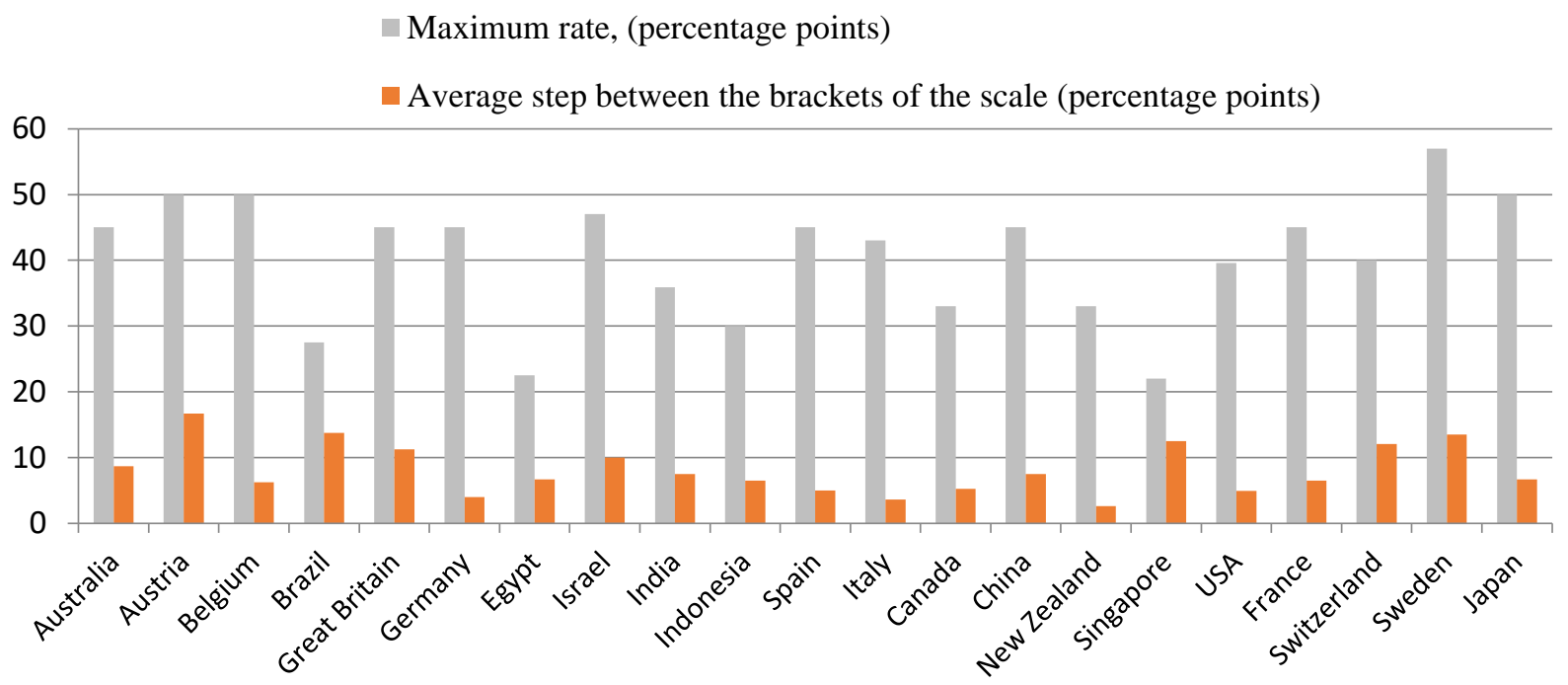

\section{Chart 1. Values of some parameters of the progressive personal income tax scale}

Source: compiled by the author using:

World Taxes Portal /(URL: http://worldtaxes.ru/)

Trading economics portal (URL: https://tradingeconomics.com/)

The Organisation for Economic Cooperation and Development portal/ (URL: https://www.oecd.org)

Our research had the aim of establishing the best number of brackets for the personal income tax in Russia, the maximum rate and an average step between the brackets of the scale without taking into consideration the exempt threshold and the initial rate. Our calculations account for the latest economic conditions. Thus, we have set the goal of creation of a statistic model with several variables.

Our correlation analysis revealed weak correlation (0.412) between the number of brackets and the percentage of GDP attributable to the personal income tax. This figure is also weakly dependent on the Gini coefficient (0.370). These indicators, however, cannot be included in the model because of their multicollinearity (-0.856). At that, the connection between the indicators and the amount of GDP per capita is practically absent. The regression analysis demonstrated the absence of a unified trend. This is why we conducted cluster analysis based on the share of the lower, middle and upper classes in wealth distribution of the states under consideration to establish the optimal number of brackets of the scale. Egypt with 6 brackets, and India with 4 brackets were most similar to Russia by their social differentiation. The states also include Brazil and China with 9 and 3 brackets of the scale respectively (Chart 2). This is why we conclude that the optimal number of brackets for Russia is 5-6 taking Egypt and India as a model since there were no serious changes in the social policies of the countries under consideration in the last 5 years.

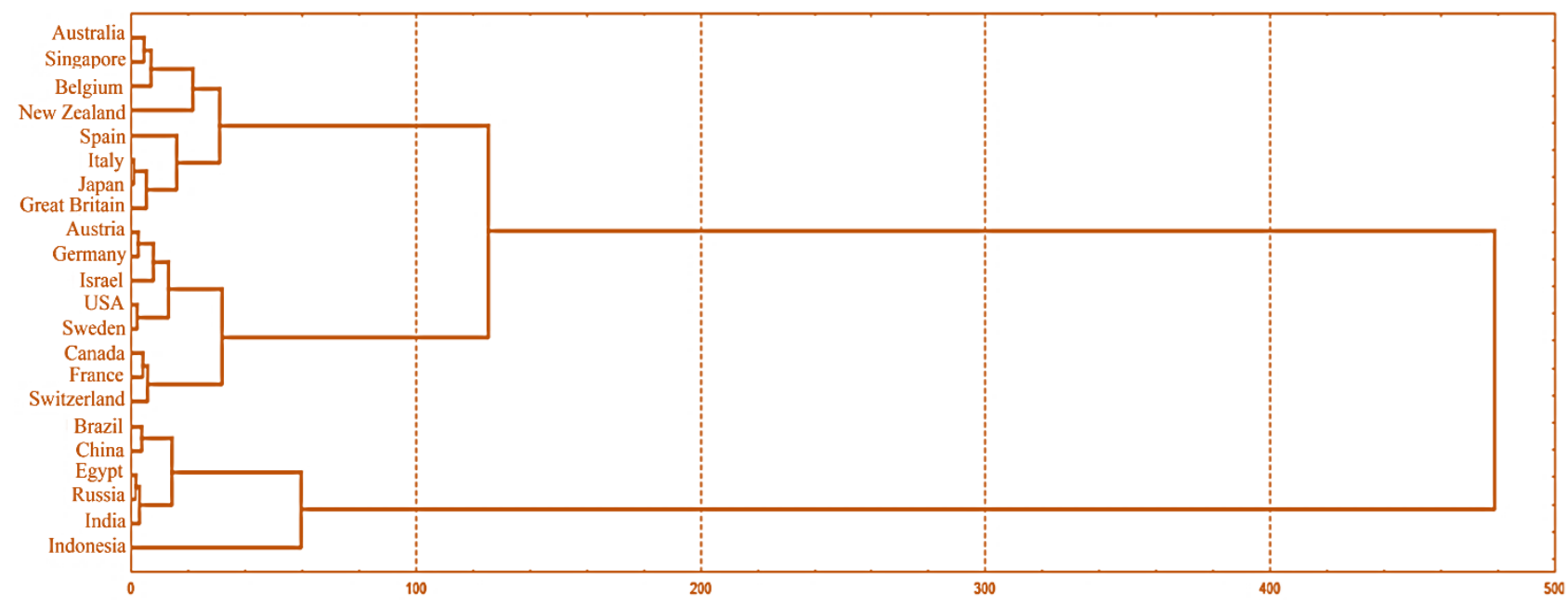


Chart 2. Hierarchical clustering of 22 states on the basis of variables of percentage distribution of wealth between the lower, middle and upper classes

Source: compiled by the author using Global Wealth Report 2015, Credit Suisse /(URL:https://www.creditsuisse.com/about-us/en/reports-research/global-wealth-report.html) and The United Nation Conference on Trade and development/UNCTADstat (URL: https://unctadstat.unctad.org/wds/ReportFolders/reportFolders.aspx?sCS ChosenLang=en) with the help of Ward's method we used the Euclidean distance, the connection distance is reflected along the abscissa axis.

Relation between the maximum value of the rate in percentage points, GDP per capita $(0.587)$ and the Gini coefficient $(-0.622)$ [12] is moderate. Exponential model $y=30,441 e^{0,0353 x}$ was selected to describe the regression. The projected value of the highest rate for the Russian Federation taking the current Gini coefficient into account amounts to $30.52 \%$, which is likely to meet the realities of the next three years.

The correlation analysis also showed weak connection between an average step of the brackets of the scale and the ratio between an average wage to a minimal wage $(-0.393)$. An average step between the brackets of the scale was calculated as a simple arithmetic mean of the differences between the neighboring brackets in percentage points, excluding the difference between the first bracket and zero, if it is above zero. This helps us given the number of brackets and the size of the maximum rate establish an approximate percentage value of the rates of each bracket. Power model $y=10,656 x^{-0,41}$ selected to describe the regression produced a projected step for Russia of 6.10 percentage points.

The proposed taxation scales for the progressive personal income tax are as follows: the rate in 6 brackets vary from 0 to 31 percent. (Ref. Table 1). The first bracket with zero taxation is supposed to apply to an income below the subsistence level or any other socially important financial indicator. We should acknowledge that the model is not full, while its values are approximate, because our research revealed only weak or moderate relation between the macroeconomic indicators and the needed parameters of the model. This pattern can be explained by the legal order of setting the rates. The governing factor is the government's vision of the most suitable order of payments for the economy and the people. Significant influence on decision making in each country is often exerted by its historical experience, traditions and the needs of a state budget, not natural processes.

Table 1 A progressive personal income tax model for the current Russian macroeconomic indicators

\begin{tabular}{|c|c|}
\hline $\begin{array}{c}\text { Numerical order of the } \\
\text { bracket of the scale }\end{array}$ & $\begin{array}{c}\text { Rate value (percentage } \\
\text { points) }\end{array}$ \\
\hline 1 & $0 \%$ \\
\hline 2 & $6 \%$ \\
\hline 3 & $12 \%$ \\
\hline 4 & $18 \%$ \\
\hline 5 & $24 \%$ \\
\hline 6 & $31 \%$ \\
\hline
\end{tabular}

Source: compiled by the author

A reduction in the number of brackets may bring the best result, or, on the contrary, their increase and raising the maximum rate. It can only be checked empirically. Experiments with the use of the personal income tax are relatively safe for the economy [2], because the share of the tax in Russia's GDP albeit higher than in China $(0.0062 \%)$ is relatively small $(0.078 \%)$. The indicators of the other states are much higher $13.1 \%$ in Sweden, $12.1 \%$ in Belgium, $11.6 \%$ in Canada and $10.9 \%$ in the U.S ${ }^{1}$. At that, the tax rates of

1 Eurostat/The statistic service of the European Union (URL: https://ec.europa.eu/eurostat) [accessed date: November 1, 2019] 
the states under consideration are sensitive to the changes in tax payers' income [6]. Although the indicator calculated when income denominated in a local currency is taxed is more realistic, we have to take into account inflation and the purchasing power parity of the currencies for appropriate comparison.

Chart 3 shows the changes in the personal income tax rate along with the changes in income per local payment unit, full percentage points.

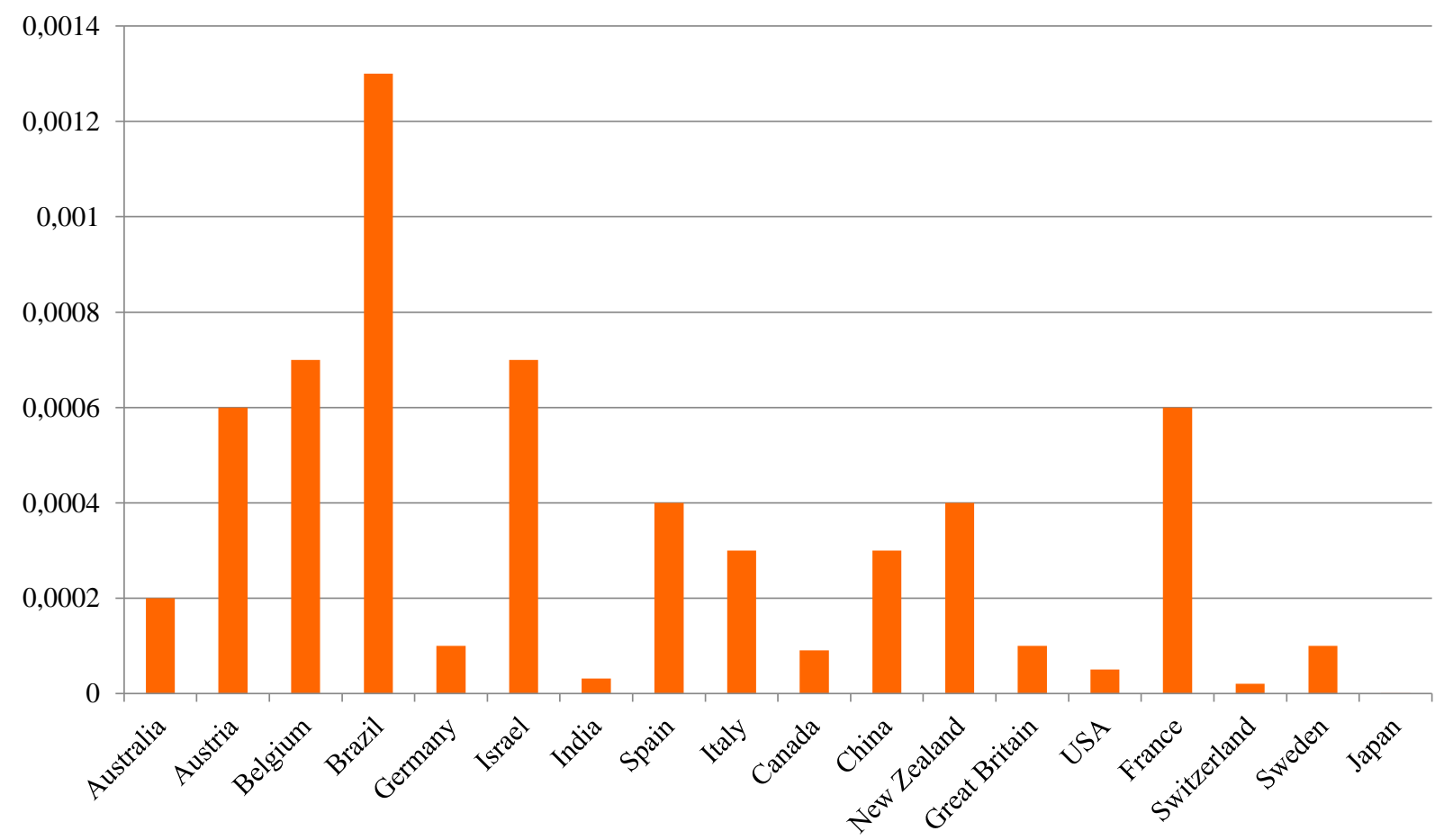

Chart 3 Changes in the personal income tax rate along with the changes in income per local payment unit, full percentage points

Source: compiled by the author. *Calculation of slopes of the trend lines of the linear regression model for each economy under consideration. We studied the rates for the childless and unmarried people. Calculation starts with the first nonzero rate. Egypt and Singapore were excluded, because the methodology of tax calculation does not imply taxation of the whole base, but gradual taxation at different rates of its parts exceeding the established thresholds. The value for Indonesia amounted to 0.00000005 IDR per percentage point of the rate, which can be explained by the special features of price formation on the labour market. Wages in the country are paid in million Indonesian rupees a month.

Besides, the methods used to calculate the aforementioned parameters cannot establish the thresholds of income. The correctness and relevance of the results of mathematical modelling here should be established empirically.

To establish the income intervals for the incomes taxed at the rate we need to:

1) Establish the share of each category of people in the personal income tax collection

2) Compare the subsistence level and the minimal wage

3) Model projected collection volumes depending on changes in income intervals for the brackets and on the changes in macroeconomic indicators and look for the best one

4) Calculate the volume of necessary benefits.

The Organization for Economic Co-operation and Development/ (URL: https://www.oecd.org) [accessed date: January $12, .2020]$ 


\section{DISCUSSION}

It is obvious that introduction of a progressive personal income tax scale will require additional instruments of monitoring and stimulation of higher legitimation of payments. On the one hand, a flat taxation scale, which was supposed to change by 2011 , does not encourage economic growth. A progressive scale could stimulate demand from the social layers with a low income, while national demand from the high-income people is unlikely to change because they prefer foreign-made products [1]. One the other hand, we have to take into account correlation of the number of tax payers with different incomes, special regional features. If the flow of tax collections diminishes as a result, subsidies will shrink. If it grows too much, there will be problems with doing business and jobs.

We should also take into account that introduction of several brackets into the system of personal income taxation is often accompanied by additional novelties increasing the effectiveness of the system's work.

First, some developed states apply a progressive personal income tax scale not to the whole tax, but for some of its components - for instance, in Norway and the Netherlands. By taxing the sums exceeding the thresholds separately the government solves the problem of social inequality [9]. The tax payers, in their turn, will not feel that they stepped over the "saving edge" and were punished for their high income, because people with different wages in this case share an equal proportion of funds with the government. For example, a single Norwegian with an income of 300,000 Norwegian krona will pay the state 9,715.41 NOK taking into account the tax exempt threshold of 220,501 NOK in the current personal income taxation system. Income below a 248,500 NOK threshold is taxed at $9.5 \%$ or 27,999 NOK. An income above the threshold, or 51,500 NOK will be taxed at a rate of $13.7 \%$. But for the ranking with an exempted minimum the tax payer would pay $10,891.36$ NOK paying a total more than his compatriot with a wage below 248,500 NOK per unit of taxation base. This means that it is the marginal part, which is taxed at a higher rate, while the people pay the same for the maximum established amounts. At that, the Gini coefficient of the countries under consideration with this type of taxation features amounts to 0.3 . It points to relatively small income differentiation.

Second, different states often do clustering and set different rates for each group of people. The heaviest tax burden falls on the unmarried childless people, and the least on the families with many children or single parents. However, the introduction of such an element will entail additional transactional costs. For example, the time and money needed to collect, process and store information about the social statuses, monitoring costs. Moreover, calculation of the personal income tax for employees, which in Russia traditionally lays with the employer, will become more complicated causing a lot of inconvenience to the business. However, breaking the tax payers by the category has its advantages. A lower burden on the families with many children can be beneficial for the demographic situation, because the available funds can have an important role in family planning [19]. Moreover, such taxation policy decreases the inequality level, while a digital economy make this approach possible. Targeted approach can also be applied via different untaxable deductions or payments. For example, Germany does not levy the tax on such forms of employee incentives as payments for child care, payments for travel to work or wellness courses.

Third, some states differentiate income tax elements depending on the region of taxation. For instance, Switzerland has rates varying from $2.6 \%$ to $15.5 \%$ deepening on the canton. The difference in conditions, which have indirect influence on income tax collection can also vary. Some Chinese provinces and regions have different minimal wages. On the one hand, such differences complicate calculation of the tax, operations of the statistical services. On the other hand, adaptation of the system to local realities helps create the most beneficial conditions to raise the living standards in the lagging regions, to soften economic inequality.

\section{CONCLUSIONS}

Thus, modification of the personal income taxation systems is not limited to the choice of the key elements. Creation of additional conditions depending on social or local features can increase the resilience and effectiveness of the system. We should keep in mind that effective tax collection is not the only goal. We should take the multiplicative effect for the national economy into consideration and a potential increase of consumption by the widest layers of the society, which is to spur up production.

Unfortunately, revealing direct functional dependence between the economies' indicators and tax rates models' elements is impossible and likewise the effective application of fully borrowed foreign taxation schemes is impossible. Moreover, personal income taxation often implies creation of special conditions for some social groups. The result of the aforementioned is weakening of the real tax burden on households. 
Undoubtedly, the establishment of the optimal number of benefits and income thresholds for raising the rate is a task, which should be solved empirically and for a long time at that. Even when the optimal amount of tax collection is reached, the model will have to be altered to support the balance in the system of the national economy due to volatility of economic factors. Such a flexible approach is especially important in the current period of foreign exchange rates instability and growing social tension.

\section{REFERENCE LIST}

1) Akhmadeev, R., Morozova, T., Voronkova, O. and Sitnov. A. (2019). Targets determination model for VAT risks mitigation at B2B marketplaces. Entrepreneurship and Sustainability Issues, vol. 7(2), p. 11971216.

2) Anil Kumar, Che-Yuan Liang, Estimating taxable income responses with elasticity heterogeneity, Journal of Public Economics, Volume 188, 2020, 104209, ISSN 0047-2727, https://doi.org/10.1016/i.jpubeco.2020.104209.

3) Avvakumova, I.V., Bykanova, O.A. and Akhmadeev, R.G. (2020) Improvement of small business owners taxation. In the Proceedings of the 7th International Conference on Education and Social Sciences (INTCESS) , p. 532-537

4) Blaine G. Robbins, Edgar Kiser, State coercion, moral attitudes, and tax compliance: evidence from a national factorial survey experiment of income tax evasion1, Social Science Research, 2020, 102448, ISSN 0049-089X, https://doi.org/10.1016/j.ssresearch.2020.102448.

5) Carlos Bethencourt, Lars Kunze, Social norms and economic growth in a model with labor and capital income tax evasion, Economic Modelling, Volume 86, 2020, Pages 170-182, ISSN 0264-9993, https://doi.org/10.1016/j.econmod.2019.06.009.

6) Chaykovskaya, L.A., Turishcheva, T. B. and Akhmadeev R. G. (2020). Functional application of the internal control system in autonomous institutions. Bulletin of the National Academy of Sciences of the Republic of Kazakhstan. vol.1 (383), p. 163 - 171.

7) Gabriele Ciminelli, Ekkehard Ernst, Rossana Merola, Massimo Giuliodori, The composition effects of taxbased consolidation on income inequality, European Journal of Political Economy, Volume 57, 2019, Pages 107-124, ISSN 0176-2680, https://doi.org/10.1016/j.ejpoleco.2018.08.009.

8) Håkan Selin, Laurent Simula, Income shifting as income creation?, Journal of Public Economics, Volume 182, 2020, 104081, ISSN 0047-2727, https://doi.org/10.1016/j.jpubeco.2019.104081.

9) Konstantinos Angelopoulos, Spyridon Lazarakis, James Malley, The distributional implications of asymmetric income dynamics, European Economic Review, Volume 128, 2020, 103502, ISSN 00142921, https://doi.org/10.1016/i.euroecorev.2020.103502.

10) Lehoux, L., Morozova, T.V., Safonova, E.G., Balashova, A.D. and Protasov, M.V. (2019) Practical Aspects in Calculating of Impairment of Financial Assets According to IFRS 9 "Financial Instruments". Proceedings of the 33rd International Business Information Management Association Conference, IBIMA 2019: Education Excellence and Innovation Management through Vision 2020, p. 6624-6632.

11) Matteo Morini, Simone Pellegrino, Personal income tax reforms: A genetic algorithm approach, European Journal of Operational Research, Volume 264, Issue 3, 2018, Pages 994-1004, ISSN 03772217, https://doi.org/10.1016/i.ejor.2016.07.059.

12) Morozova, T., Akhmadeev, R., Lehoux, L., Yumashev, A., Meshkova, G. and Lukiyanova, M. (2020). Crypto asset assessment models in financial reporting content typologies, Entrepreneurship and Sustainability Issues, vol.7(3), p. 2196-2212.

13) Petrova G., Posadneva E. and Morozova T. (2019) Leading the labour market by the law of supply and demand. Sustainable Leadership for Entrepreneurs and Academics. Springer Proceedings in Business and Economics. p. 263-271. 
14) Riccardo Magnani, Luca Piccoli, Universal basic income with flat tax reform in France, Journal of Policy Modeling, Volume 42, Issue 2, 2020, Pages 235-249, ISSN 0161-8938, https://doi.org/10.1016/i.jpolmod.2019.07.005.

15) Sharafutdinov, R., Gerasimov, V., Akhmetshin, E., Karasik, E. and Kalimullina, O. (2019). Inclusive development index in Russia: analysis, methods, possibility of application. Revista Genero \& Direito, vol. 8(4), p. 231-241.

16) Turishcheva T., Akhmadeev R., Bykanova O. and Nastasyuk N. (2020) Methodological Support for Internal Control of Autonomous Institutions. International Journal of Applied Exercise Physiology. vol. 9 (4), p.53-61

17) Turishcheva, T.B., Ponomareva, D.A. and Luzgina, A.S. (2019) Review of the key requirements for the financial statements complying with the international and Russian accounting standards. Proceedings of the 33rd International Business Information Management Association Conference, IBIMA 2019: Education Excellence and Innovation Management through Vision 2020, p. 3031-3039

18) Valerio Dotti, Income inequality, size of government, and tax progressivity: A positive theory, European Economic Review, Volume 121, 2020, 103327, ISSN 0014-2921, https://doi.org/10.1016/i.euroecorev.2019.103327.

19) Zaporozhtseva, L., Malitskaya, V., Chirkova, M., Tkacheva, Y. and Kuznetsova, I.(2020). Financial mechanism for commercial organization development: vector approach. International Transaction Journal of Engineering, Management \& Applied Sciences \$ Technologies, vol.11 (7). 